Dhaka Univ. J. Biol. Sci. 26(1): 29-38, 2017 ( January)

\title{
CADMIUM AND LEAD TOLERANT BACTERIA ISOLATED FROM INDUSTRIAL WASTE WATER
}

\author{
Md Arifur Rahman Bhuiyan, Tazeen Fatima Khan, \\ SHAHJAHAN CHOUdHuRY AND SM IMAMUl HuQ* \\ Bangladesh-Australia Centre for Environmental Research, Department of Soil, Water and \\ Environment, University of Dhaka, Dhaka-1000, Bangladesh
}

Key words: Heavy metal, Waste water, Bacteria, Metal resistant

\begin{abstract}
An in vitro study was conducted to isolate, identify and characterize heavy metal resistant bacteria from industrial waste water and to determine their tolerance capacity to cadmium and lead. Different morphological, physiological and biochemical tests were carried out to identify the bacterial isolates in the waste water. A total of eight bacterial isolates viz., Staphyllococcus intermedius, Pseudomonas aeruginosa, Bacillus cereus, Bacillus subtilis, Escherichia coli, Acinetobacter baumanii, Pseudomonas flavescens and Acinetobacter lwofii were identified from metal polluted tannery and steel industrial areas. Bacterial response to cadmium tolerance was determined by treating them with $\mathrm{CdCl}_{2}$ solution at a rate of $1,2,2.5$ and $5 \mu \mathrm{g} / \mathrm{ml}$. In case of lead tolerant bacteria, $\mathrm{PbCl}_{2}$ solution was applied at a rate of $0.05,0.125,0.2$ and $0.5 \mu \mathrm{g} / \mathrm{ml}$. Pseudomonas aeruginosa isolated from waste water of steel industries and Bacillus cereus from tannery area was found to be the most tolerant species to the different doses of cadmium and lead. The study indicated that Pseudomonas aeruginosa and Bacillus cereus could be good candidates for the treatment and elimination of heavy metals from industrial waste water. The present study may be helpful to the bioremediation of heavy metals in the contaminated environment.
\end{abstract}

\section{Introduction}

Heavy metal contamination due to natural and anthropogenic sources is a global environmental concern. Human activities, such as mining operations and the discharge of industrial wastes, result in the accumulation of metals in the environment and are eventually accumulated through the food chain, leading to serious ecological and health problems ${ }^{(1-2)}$. The pollution of the ecosystem by heavy metals is a real threat to the environment because metals cannot be naturally degraded like organic pollutants and persist in the ecosystem being accumulated in different parts of the food chain(3). These heavy metals influence the microbial population by affecting their growth, morphology, biochemical activities and ultimately resulting in decreased biomass and diversity ${ }^{(4)}$.

\footnotetext{
*Author for correspondence: <imamhuq@hotmail.com>.
} 
Toxic metal tolerance of bacteria has been studied for many years but considering the range of toxic metal ions and diversity of microbes, the overall efforts appear to be limited. However, there is no general mechanism for tolerance to all toxic metals(5), as there are evidences for both chromosomal and plasmid borne genes for tolerance ${ }^{(6)}$. The ability of microbial strains to grow in the presence of heavy metals would be helpful in the wastewater treatment where microorganisms are directly involved in the decomposition of organic matter in biological processes for wastewater treatment, because often the inhibitory effect of heavy metals is a common phenomenon that occurs in the biological treatment of wastewater and sewage ${ }^{(7)}$.

Most of the studies regarding the tolerance of heavy metal toxicity by microorganisms were focused on soil quality. Therefore, the effects of heavy metals on bacteria living in wastewater need to be studied. The current study aimed at assessing the tolerance capacity of bacterial isolates present in industrial wastewater to the heavy metals particularly cadmium and lead.

\section{Materials and Methods}

Sampling sites: The steel industrial area in Savar and tannery area in Hazaribagh, both places being adjacent to Dhaka, were selected for the collection of waste water samples that were contaminated with steel industry effluents, waste water and tannery effluents. Waste water was collected from drains as well as from corresponding rivers in which waste water was discharged. The georeferences of the sampling sites in tannery area are $23.738961^{\circ} \mathrm{N}$ and $90.367615^{\circ} \mathrm{E}$ (Hazaribagh Tannery intersection); $23.734852^{\circ} \mathrm{N}$ and $90.354983^{\circ} \mathrm{E}$ (Buriganga River). The georeferences of the sampling sites in steel industrial area are $23.846188^{\circ} \mathrm{N}$ and $90.243359^{\circ} \mathrm{E}$ (Ulail, Savar bazaar); $23.845975^{\circ} \mathrm{N}$ and $90.242471^{\circ}$ E (Dhalshwari River).

Collection and preservation of waste water samples: Sterilized sampling bottles were used to collect waste water. The bottles were rinsed 2 to 3 times with the water being collected, and then these were filled up to the top and sealed carefully so that no air could enter into the bottles. Collection of water samples were done by following composite sampling techniques as described in Imamul Huq and Alam ${ }^{(8)}$. For microbiological analysis, collected samples were kept in cool and dark place before and after the analysis so the sample does not deteriorate and the analytical results were representative.

Determination of cadmium and lead concentrations in waste water samples: To determine the total cadmium and lead concentration present in the water samples, the water samples were digested using "Aqua Regia" $\left(\mathrm{HNO}_{3}: \mathrm{HCl}=1: 3\right)$ solution. Waste water sample was mixed with aqua regia solution at a ratio of $10: 1$ followed by heating in a digestion chamber. When the solution became one third of its initial volume, the sample was thoroughly treated with distilled water, filtered and collected into $50 \mathrm{ml}$ volumetric 
flask. The concentration of total cadmium and lead was determined by using a VARIAN Atomic Absorption Spectrophotometer (AAS)(8). For every ten samples a Certified Reference Material (CRM) was included to ensure quality control/quality assurance (QC,QA).

Culture of bacteria: For culture of bacteria, simple "Pour Plate Technique" was followed as described by Khan and Huq(9).

Isolation of cadmium and lead tolerant bacteria: For isolation of cadmium and lead tolerant bacteria, unsterilized waste water samples were used as source to grow the bacteria. First, bacteria were grown on solidified agar plates and were kept in incubation at $37^{\circ} \mathrm{C}$ for $24 \mathrm{hrs}$. Then purification of the isolates (pure culture) was done. At the same time a portion of the collected waste water samples was sterilized to kill the existing bacteria but concentration of heavy metals remained same. This sterilized water was then applied on bacteria to test their metal tolerance. For this purpose, $5 \mathrm{ml}$ of the sterilized waste water was applied to each of the isolates and then incubated for 3 days at $37^{\circ} \mathrm{C}$. The isolates that were capable of growing new colonies within this time span were considered as heavy metal tolerant, particularly cadmium and lead tolerant ${ }^{(10)}$. Following the colony morphology, gram staining, spore staining and relevant biochemical tests, isolated bacteria were identified according to the "Bergey's Manual of Determinative Bacteriology"(11).

Determination of bacterial response to cadmium and lead tolerance: Cadmium and lead containing salts, namely $\mathrm{CdCl}_{2} \cdot \mathrm{H}_{2} \mathrm{O}$ and $\mathrm{PbCl}_{2}$ were used to prepare $1000 \mathrm{mg} /$ stock solution of each. Each stock solution was filter-sterilized and added to the nutrient broth media at varying concentrations of metals to determine their tolerance capacity ${ }^{(12)}$. The concentrations of heavy metals applied to assess the tolerance of the isolated bacteria were determined on the basis of the background concentration of waste water. For this, concentrations of 1, 2, 2.5 and $5 \mu \mathrm{g} / \mathrm{ml}$ of $\mathrm{CdCl}_{2}$ and $0.05,0.125,0.2$ and $0.5 \mu \mathrm{g} / \mathrm{ml}^{\text {of } \mathrm{PbCl}_{2}}$ were added in media. These concentrations were actually $50 \%$ higher than sample concentrations. In case of control, no treatments were used. Then identified isolates were incubated in duplicate tubes containing heavy metals of different concentrations added with nutrient broth and incubated at $37^{\circ} \mathrm{C}$ for $24,48,72,96$ and $120 \mathrm{hrs}$, respectively. After incubation, growth of bacteria in liquid media was confirmed by the formation of white precipitate. At $24 \mathrm{hrs}$ intervals, the optical density of each of the samples were determined at $580 \mathrm{~nm}$ by using spectrophotometer in order to determine the growth response of each isolates treated with different concentration of cadmium and lead ${ }^{(13)}$.

Statistical analysis: The experimental data were statistically analyzed by using the Microsoft Excel and STATA (version 12). T-test was done to know whether or not there was significant difference among the selected bacteria. 


\section{Results and Discussion}

Bacterial response to cadmium tolerance: A total of four bacterial species were identified as cadmium and lead tolerant from the waste water samples: these were Staphyllococcus intermedius, Pseudomonas aeruginosa, Bacillus cereus and Acinetobacter baumanii. The results of the optical density of the four bacterial species each treated with 1, 2, 2.5 and $5 \mu \mathrm{g} / \mathrm{ml}$ of $\mathrm{CdCl}_{2}$ for the period of 24, 48, 72, 96 and 120 hrs are shown in Figs 1-4.

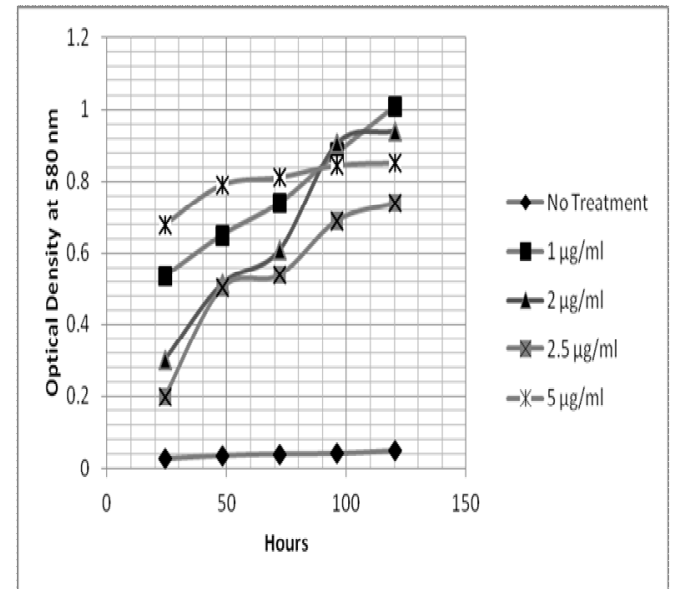

Fig. 1. Growth of Staphyllococcus intermedius at different concentrations of $\mathrm{CdCl}_{2}$.

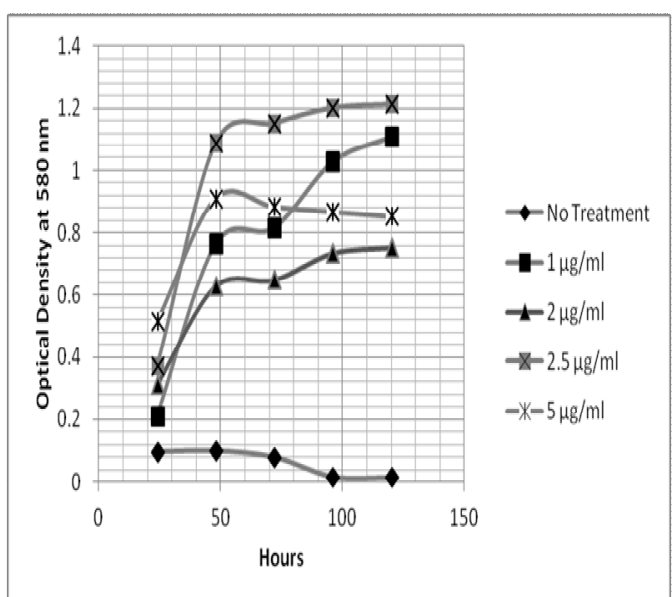

Fig. 3. Growth of Bacillus cereus at different concentrations of $\mathrm{CdCl}_{2}$.



Fig. 2. Growth of Pseudomonas aeruginosa at different concentrations of $\mathrm{CdCl}_{2}$.

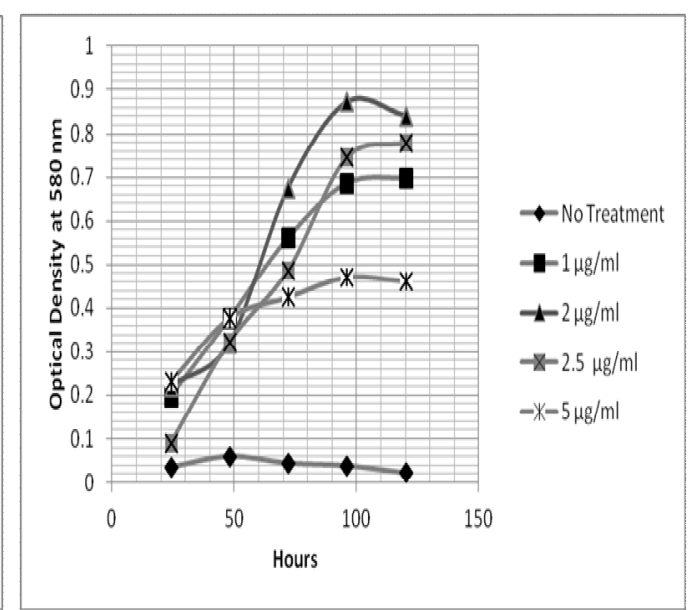

Fig. 4. Growth of Acinetobacter baumanii at different concentrations of $\mathrm{CdCl}_{2}$.

It is clear from the Fig. 1 that initially the growth continued for $120 \mathrm{hrs}$ ( 5 days) at 1 $\mu \mathrm{g} / \mathrm{ml}$ concentration but the growth decreased at $5 \mu \mathrm{g} / \mathrm{ml}$. Bruins et al. (14) reported that, Staphyllococcus aureus strains treated with $\mathrm{Cd}^{2+}$ showed highest resistance probably 
caused by the efflux pumps. Figure 2 indicates that the growth response of Pseudomonas aeruginosa at different concentrations of $\mathrm{CdCl}_{2}$ was satisfactory and it showed its best response at $5 \mu \mathrm{g} / \mathrm{ml}$ at which the growth seemed to be increasing even after $120 \mathrm{hrs}$. The growth responses at other concentrations were also satisfactory and it showed its moderate response at 1 and $2 \mu \mathrm{g} / \mathrm{ml}$.

Hassen et al.(15) and Hussein et al.(16) isolated a Cd-resistant Pseudomonas aeruginosa with minimum inhibitory concentration of $1.5 \mathrm{mM}$ in nutrient broth. On the other hand, Malik ${ }^{(17)}$ reported that Pseudomonas strain - H1 isolated from soil was resistant to $225 \mathrm{ppm}$ $\mathrm{Cd}^{2+}$. The growth response of Bacillus cereus (Fig. 3) continued to increase upto $2.5 \mu \mathrm{g} / \mathrm{ml}$ but after that it dropped at the highest concentration of $5 \mu \mathrm{g} / \mathrm{ml}$. The growth nearly leveled off after $96 \mathrm{hrs}$ at $5 \mu \mathrm{g} / \mathrm{ml}$ concentration but the overall growth response at different concentrations of $\mathrm{CdCl}_{2}$ was moderately satisfactory. Although the metal tolerance response by Acinetobacter baumanii was initially satisfactory (Fig. 4) upto 2 $\mu \mathrm{g} / \mathrm{ml}$ but after that the curves tended to decrease. However, the growth rapidly decreased at $5 \mu \mathrm{g} / \mathrm{ml}$ and seemed to be almost leveled after $96 \mathrm{hrs}$ (4 days).

Raja ${ }^{(18)}$ reported that Acinetobacter radioresistens isolated from sewage water collected in and around Madurai district, South India was resistant to $\mathrm{Cd}(4-7 \mathrm{mM}), \mathrm{Cr}(0.7 \mathrm{mM})$, $\mathrm{Ni}(6.75$ - $8.5 \mathrm{mM}), \mathrm{Pb}(6 \mathrm{mM})$, As $(6.5-15 \mathrm{mM})$ and $\mathrm{Hg}(0.75 \mathrm{mM})$.

Bacterial response to lead tolerance: Four metal tolerant bacteria were treated at a rate of 0.05, 0.125, 0.2 and $0.5 \mu \mathrm{g} / \mathrm{ml}$ of $\mathrm{PbCl}_{2}$ solution and incubated for 24, 48, 72, 96 and 120 hrs. Then optical density was measured at $24 \mathrm{hrs}$ intervals which indicated the metal tolerance response of the isolates. The results of the optical density are shown in Figs 5-8.

It is evident from Fig. 5 that initially the tolerance response of Staphyllococcus intermedius was satisfactory at 0.05 and $0.125 \mu \mathrm{g} / \mathrm{ml} \mathrm{of} \mathrm{PbCl}_{2}$ but after that the growth response was drastically reduced at 0.2 and $0.5 \mu \mathrm{g} / \mathrm{ml}$. It is observed from Fig. 6 that Pseudomonas aeruginosa responded best at $0.5 \mu \mathrm{g} / \mathrm{ml} \mathrm{PbCl}$ concentration and the growth seemed to be continuing even after $120 \mathrm{hrs}$ ( 5 days). Selvi et al. ${ }^{19)}$ reported that more than $80 \%$ of Pseudomonas sp., $70 \%$ of the E. coli, $50 \%$ of Bacillus, $90 \%$ of Flavobacterium and $90 \%$ of Alcaligens isolated from tannery effluents were found resistant against lead. Minimum inhibitory concentrations (MIC) of lead was found to be $60-80,80$ and $70 \mathrm{ppm}$ for Escherichia coli, Alcaligenes sp. and Pseudomonas sp., respectively.

It is clear from Fig. 7 that the growth response of Bacillus cereus at different concentrations indicated a higher metal tolerance response. It showed its best growth response at concentration of $0.5 \mu \mathrm{g} / \mathrm{ml} \mathrm{PbCl}_{2}$ and the growth seemed to be continuing even after 120 hours (5 days). Growth responses at other concentrations were also satisfactory. According to Murthy et al.(20) Bacillus cereus showed remarkable ability to remove lead from media. Lead concentrations of 200, 300, 400 and $500 \mathrm{mg} /$ were reduced to $75.6,56.7,41.8$ and $39.1 \%$, respectively, from the medium after $72 \mathrm{hrs}$. It is clear from 
Fig. 8 that Acinetobacter baumanii showed its best growth response at $0.5 \mu \mathrm{g} / \mathrm{ml}$. However, the growth response was more or less moderate at other concentrations.

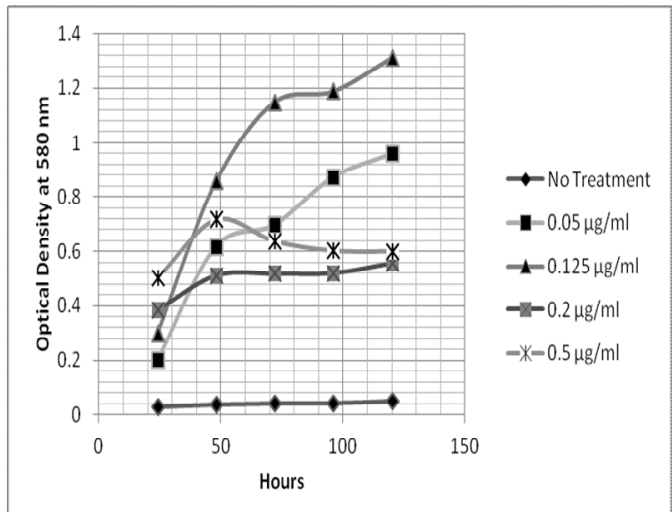

Fig. 5. Growth of Staphyllococcus intermedius at different concentrations of $\mathrm{CdCl}_{2}$.

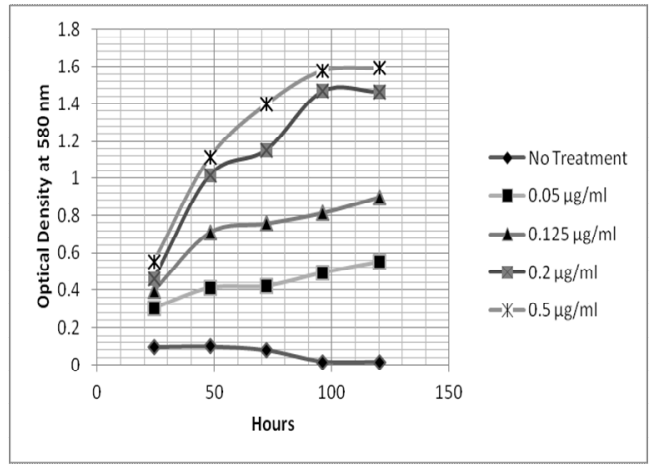

Fig. 7. Growth of Bacillus cereus at different concentrations of $\mathrm{CdCl}_{2}$

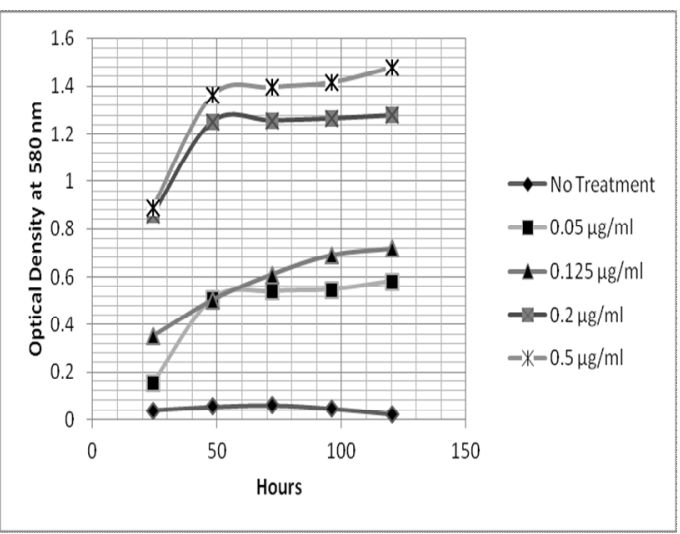

Fig. 6. Growth of Pseudomonas aeruginosa at different concentrations of $\mathrm{CdCl}_{2}$.

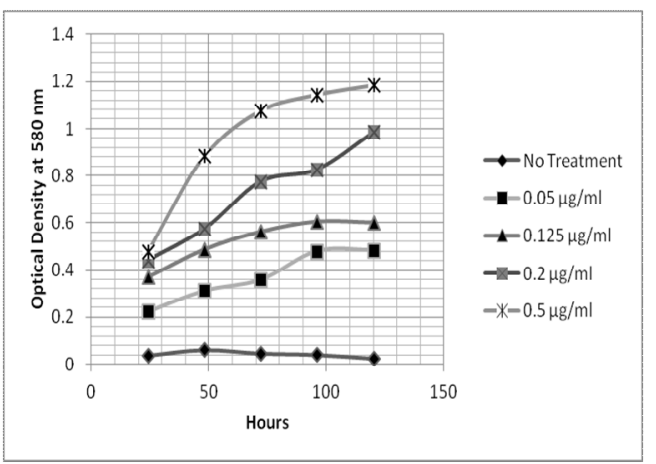

Fig. 8. Growth of Acinetobacter baumanii at different concentrations of $\mathrm{CdCl}_{2}$.

Comparative cadmium and lead tolerance of the isolated bacteria: Optical density of the four bacterial isolates was measured at the highest concentration levels $(5 \mu \mathrm{g} / \mathrm{ml}$ for $\mathrm{CdCl}_{2}$ and $0.5 \mu \mathrm{g} / \mathrm{ml}$ for $\mathrm{PbCl}_{2}$ ). Comparison of cadmium and lead tolerance capacity of these isolates are shown in Figs 9-10.

It is evident from Fig. 9 that Pseudomonas aeruginosa showed its highest tolerance response to $\mathrm{CdCl}_{2}$ at $5 \mu \mathrm{g} / \mathrm{ml}$ and the growth seemed to be continuing even after $120 \mathrm{hrs}$ (5 days). The least tolerance to $\mathrm{CdCl}_{2}$ was shown by Acinetobacter baumanii. On the contrary, Bacillus cereus showed an initial growth response up to $72 \mathrm{hrs}$ but after that the growth leveled off. Staphyllococcus intermedius showed moderate response for cadmium and the trend seemed to be almost similar with that of Bacillus cereus. Both Bacillus cereus 
and Staphyllococcus intermedius showed moderate tolerance to $5 \mu \mathrm{g} / \mathrm{ml}$ of $\mathrm{CdCl}_{2}$. Bacteria of the genus Pseudomonas are well-studied and are of great interest not only because of their high resistance to heavy metals and other toxic substances, but also for their simple nutritional requirements and rapid growth on standard laboratory media(21). In the laboratory, Pseudomonas aeruginosa showed resistance to high concentrations of $\mathrm{Zn}, \mathrm{Cu}$, $\mathrm{Ni}, \mathrm{Pb}, \mathrm{Cd}$ and $\mathrm{Hg}$. Whatever may be the case, the highest cadmium tolerance response was observed in the bacteria - Pseudomonas aeruginosa(22-23).

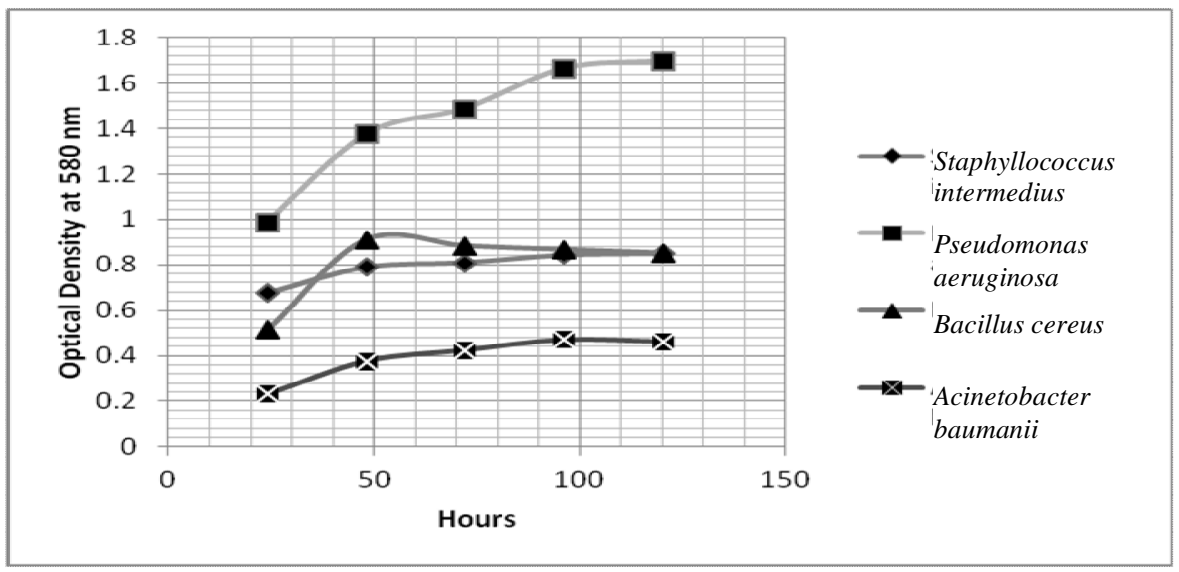

Fig. 9. Comparison of growth response of the isolates at $5 \mu \mathrm{g} / \mathrm{ml} \mathrm{CdCl}_{2}$.

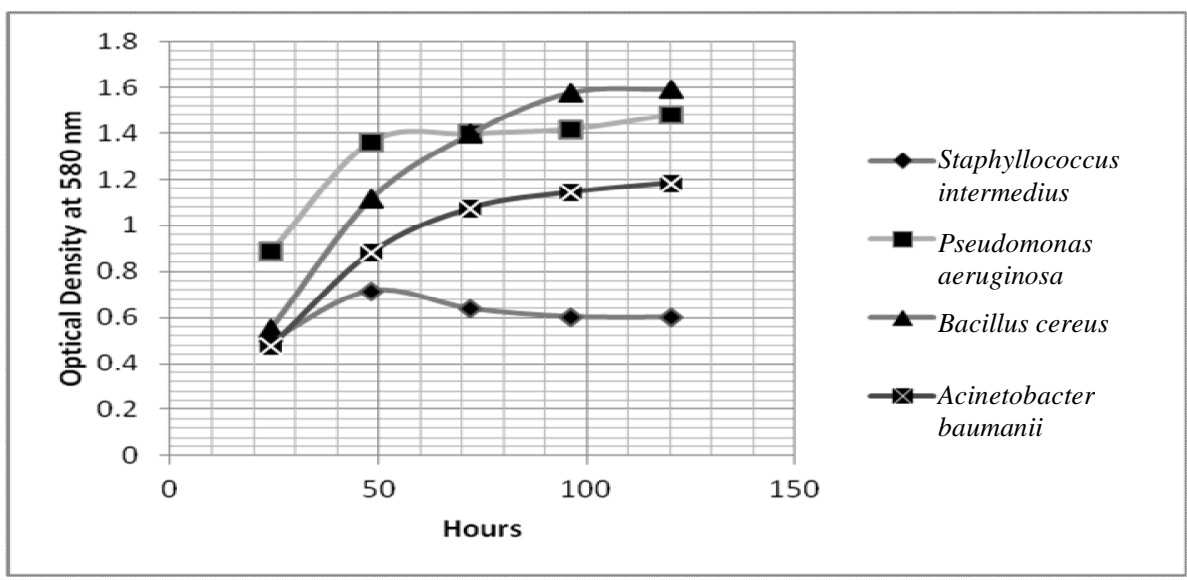

Fig. 10. Comparison of growth response of the isolates at $0.5 \mu \mathrm{g} / \mathrm{ml} \mathrm{PbCl}_{2}$.

Figure 10 clearly shows that among the four isolates, Bacillus cereus showed its best performance and the highest tolerance response at $0.5 \mu \mathrm{g} / \mathrm{ml} \mathrm{of} \mathrm{PbCl}_{2}$ solution. The reasons could be that high metal concentration influences increased enzyme activity, increased respiration rate as well as normal regeneration system. The second best tolerance response was observed in Pseudomonas aeruginosa and the trend seemed to be 
continuing after $120 \mathrm{hrs}$ (5 days) and it did not show any declining trend even after that time. Acinetobacter baumanii showed its moderate tolerance response against $0.5 \mu \mathrm{g} / \mathrm{ml}$ of $\mathrm{PbCl}_{2}$. The least tolerance response was observed for Staphyllococcus intermedius. Its highest tolerance response was observed at $48 \mathrm{hrs}$, but after that the trend seemed to be almost leveled off indicating its lowest tolerance capacity against lead. According to Murthy et al.(20) the lead biosorption capability of Bacillus cereus was studied at different concentrations $(100,200,300,400$ and $500 \mathrm{mg} \Lambda$ ) of lead. Studies revealed that an optimum temperature of $30^{\circ} \mathrm{C}$ and $\mathrm{pH}$ of 5.0 facilitate the maximum biosorption of lead by $24 \mathrm{hrs}$ old culture of Bacillus cereus.

The removal of lead by Bacillus cereus revealed that the percentage of metal removed by the bacteria decreases with increasing concentration of lead. The enhancement in metal sorption could be due to the increase in electrostatic interactions involving sites of progressively lower affinity for metal ions. Toxicity testing in liquid media allows a good evaluation of metal toxicity in polluted environments, such as industrial effluents and sewage sludge leachates ${ }^{(24)}$. Liquid media toxicity testing is different from toxicity testing on solid media, where the conditions of diffusion, complexation and availability of metals are different from those in solid media.

Hassen et al.(24) also tested the levels of tolerance of environmental bacteria to the different divalent metal ions including $\mathrm{Cu}^{2+}, \mathrm{Co}^{2+}, \mathrm{Cd}^{2+}$ and $\mathrm{Zn}^{2+}$ in nutrient broth. $\mathrm{He}$ reported that the test in liquid media was sensitive at concentrations that are 10 to 1000 times lower than those obtained in solid media. Scientists revealed that most bacterial isolates were resistant to very high concentrations of heavy metals regardless of the level of metal concentrations in their environment. They also discovered that the most predominant isolates at high concentrations of the metal ions include Bacillus spp., Pseudomonas spp., Corynebacterium spp., Micrococcus spp., Flavobacterium spp., Proteus, Citrobacter, Alcaligenes and Enterobacter(25).

In case of cadmium tolerance, the t-test indicated that Staphyllococcus intermedius showed significant difference ( $\mathrm{p}=0.0058, t=4.9305$ and $\mathrm{p}=0.001, t=7.4726)$ with rest of the bacteria whereas it showed no significant difference with Bacillus cereus ( $p=0.8973$, $t=0.1352)$. In case of lead tolerance, the $t$-test showed significant differences $(\mathrm{p}=0.003$, $t=6.2073 ; \mathrm{p}=0.0122, t=3.2232$ and $\mathrm{p}=0.0352, t=2.5313$ ) among Bacillus cereus, Pseudomonas aeruginosa and Acinetobacter baumanii.

Although the conditions in which bacteria grow actually differ from laboratory to natural environment yet it can be concluded from the study that both Pseudomonas aeruginosa and Bacillus cereus could be used in bioremediation of metal contaminated waste water particularly cadmium $(\mathrm{Cd})$ and lead $(\mathrm{Pb})$.

The presence of these metals in the environment can alter the biomass, diversity, population as well as growth and survival of bacterial communities. The present study 
might provide a basis for broader investigation of metal tolerant bacteria considering their potential use towards bioremediation.

\section{Acknowledgements}

The first author is grateful to the Ministry of Science and Technology, Government of the People's Republic of Bangladesh, for providing an S \& T scholarship to financially support the present research.

\section{References}

1. Cheng S 2003. Heavy metals in plants and phytoremediation. Environ. Sci. Pollut. Int. Res. 10: $335-340$.

2. Chisti Y 2004. Environmental impacts of toxic pollutants. Biotechnol. Adv. 6: 431-432.

3. Igwe JC, IC Nnorom and BCG Gbaruko 2005. Kinetics of radio nuclides and heavy metals behavior in soils: Implications for plant growth. African J. Biotechnol. 4(B): 1541-1547.

4. Roane TM and ST Kellogg 2000. Characterization of bacterial communities in heavy metal contaminated soils. Canadian J. Microbiol. 42: 593-603.

5. Trevors JT, GW Stratton and GM Gadd 1986. Cadmium transport, resistance, and toxicity in bacteria, algae, and fungi. Canadian J. Microbiol. 32: 447-464.

6. Hassan MET, DV Lelie, D Springael, U Romling, N Ahmed and M Mergeay 1999. Identification of a gene cluster, czr, involved in cadmium, and zinc resistance in Pseudomonas aeruginosa. Gen. Microbiol. 238: 417-425.

7. Filali BK, J Taoufik, Y Zeroual, FZ Dzairi, M Talbi and M Blaghen 2000. Waste water bacteria resistant to heavy metals and antibiotics. Current Microbiol. 41: 151-156.

8. Imamul Huq SM and MD Alam 2005. A handbook on analysis of soil, plant, and water. BACERDU, University of Dhaka, Bangladesh. pp. 37-102.

9. Khan TF and SM Imamul Huq 2014. Effects of biochar on the abundance of soil bacteria. British Microbiol. Res. J. 4(9): 896-904.

10. Hardoyo KJ and H Ohtake 1991. Harmful effects of heavy metal cations and chromate reduction by Enterobacter doaceae strain. J. Gen. Appl. Microbiol. 37: 519.

11. Bergey DH 1957. Bergey's manual of determinative bacteriology. Wilkins and Wilkins, Baltimore, United Sates. pp. 353-413.

12. Mergeay M, D Nies, HG Schlegel, J Gerits, P Charles and F van Gijsegem 1985. Alcaligenes eutrophus $\mathrm{CH} 34$ is a facultative chemolithotroph with plasmid bound resistance to heavy metals. J. Bacteriol. 3: 691-698.

13. Rathnayake IVN, M Megharaj, N Bolan and R Naidu 2009. Tolerance of heavy metals by Gram-positive soil bacteria. Int. J. Biol. Biochem. Agri. Forest. Biotechnol. 3(5): 270-273.

14. Bruins MR, S Kapil and FW Oehme 2000. Microbial resistance to metals in the environment. Ecotox. Environ. Safe. 45: 198-207.

15. Hassen A, N Saidi, M Cherifand and A Boudabous 1998. Resistance of environmental bacteria to heavy metals. Biores. Technol. 64: 7-15. 
16. Hussein H, S Farag, K Kandil and H Moawad 2005. Tolerance and uptake of heavy metals by Pseudomonas. Process Biochem. 40: 955-961.

17. Malik A 2004. Metal bioremediation through growing cells. Environ. Int. 30: 261-278.

18. Raja CE, GS Selvam and K Omine 2009. Isolation, identification and characterization of heavy metal resistant bacteria from sewage. International Joint Symposium on Geodisaster Prevention and Geo environment in Asia. JS-Fukuota.

19. Selvi T, E Anjugam, AR Devi, B Madhan, S Kannappan and B Chandrasekaran 2012. Isolation and characterization of bacteria from tannery effluent treatment plant and their tolerance to heavy metals and antibiotics. Asian J. Exp. Biol. Sci. 3(1): 34-41.

20. Murthy S, G Bali and SK Sarangi 2012. Biosorption of lead by Bacillus cereus isolated from industrial effluents. British Biotechnol. 2(2): 73-84.

21. Pardo R, M Herguedas, E Barrado and M Vega 2003. Biosorption of cadmium, copper, lead and zinc by inactive biomass of Pseudomonas putida. Anal. Bioanal. Chem. 376: 26-32.

22. Wang CL, Michels, PC Schott, C Sawson, S Kitisakkul, JA Baross, JD Keasling and DS Clark 1997. Cadmium removal by a new strain of Pseudomonas aeruginosa in aerobic culture. Appl. Environ. Microbiol. 63: 4075-4078.

23. Teitzel GM and MR Parsek 2003. Heavy metal resistance of biofilm and planktonic Pseudomonas aeruginosa. Appl. Environ. Microbiol. 69: 2313-2320.

24. Hassen A, N Saidi, M Cherifand and A Boudabous 1998. Resistance of environmental bacteria to heavy metals. Biores. Technol. 64: 7-15.

25. Anyanwu CU and ON Nwachukwu 2011. Heavy metal resistance in bacteria isolated from contaminated and uncontaminated soils. Int. J. Res. Chem. Env. 1: 173-178.

(Manuscript received on 2 October, 2016; revised on 12 December, 2016) 